\title{
Effect of chronic treatment with the gonadotrophin-releasing hormone agonist azagly-nafarelin on basal concentrations of $\mathrm{LH}$ in prepubertal bulls
}

\author{
H. Jiménez-Severiano ${ }^{1,2 *}$, M. J. D'Occhio ${ }^{3 \dagger}$, D. D. Lunstra ${ }^{4}$, M. L. Mussard ${ }^{1,2}$, \\ J. W. Koch ${ }^{1 \ddagger}$, L. R. Ehnis ${ }^{1 \S}$, W. J. Enright ${ }^{5}$ and J. E. Kinder ${ }^{1,2,}$ \\ ${ }^{1}$ Department of Animal Science, University of Nebraska, Lincoln, NE 68583-0908, USA; \\ ${ }^{2}$ Department of Animal Sciences, The Ohio State University, 2029 Fyffe Road, Columbus, \\ $\mathrm{OH}$ 43210-1095, USA; ${ }^{3}$ Animal Sciences and Production Group, Central Queensland University, \\ Rockhampton, Queensland, Australia 4701; ${ }^{4}$ The US Department of Agriculture, Agriculture Research \\ Service, Roman L. Hruska US Meat Animal Research Center, Clay Center, NE 68933-0166, USA; and \\ ${ }^{5}$ Intervet International, 5830 AA Boxmeer, The Netherlands
}

\begin{abstract}
Administration of GnRH agonist for an extended period inhibits pulsatile $\mathbf{L H}$ release but enhances testicular function of bulls. The mechanism whereby long-term administration of GnRH agonist enhances testosterone concentration in the blood of bulls has not been determined. The aim of this study was to determine whether chronic treatment with the GnRH agonist, azagly-nafarelin, increases blood concentrations of $\mathrm{LH}$ and $\mathrm{FSH}$ in prepubertal bulls. Two different doses of the GnRH agonist were administered via Alzet mini-osmotic pumps for 28 days. Blood samples were collected at 20 min intervals for $24 \mathrm{~h}$ at days 2, 13 and 25 of treatment. Agonist-treated groups had reduced testosterone pulse frequency $(P<0.05)$ and
\end{abstract}

increased mean and basal concentrations of testosterone $(P<0.05)$ compared with untreated control bulls. Basal LH concentrations were higher in agonist-treated bulls during all three periods $(P<0.05)$ and overall $\left(1 \mathrm{ng} \mathrm{ml}^{-1}\right.$ higher, compared with control bulls; $P<\mathbf{0 . 0 0 1}$ ). Frequency of $\mathrm{LH}$ pulses in the agonist-treated groups was reduced to less than one pulse in $24 \mathrm{~h}$. Agonist-treated bulls tended to have $(P<0.10)$ or had $(P<0.05)$ a slight but significant increase in blood FSH concentration. In conclusion, the higher blood testosterone concentration in bulls after prolonged treatment with GnRH agonist may result, at least in part, from changes in the testes induced by enhanced basal concentration of $\mathrm{LH}$.

\section{Introduction}

Chronic treatment with $\mathrm{GnRH}$ or $\mathrm{GnRH}$ agonist induces desensitization of the anterior pituitary gland (Labrie et al., 1980; Bint Akhtar et al., 1983; Schürmeyer et al., 1984; Lincoln et al., 1986). In many species, including rats (Labrie et al., 1980), rhesus monkeys (Bint Akhtar et al., 1983; Sundaram et al., 1984), dogs (Vickery et al., 1985), humans (Schürmeyer et al., 1984) and sheep (Fraser and Lincoln, 1980; Lincoln et al., 1986),

\footnotetext{
*Present address: CENID Fisiologia Animal, INIFAP-SAGARPA. Apdo. Postal 2-29, Queretaro, Qro. CP 76020, Mexico $\dagger$ Present address: University of Queensland-Gatton Campus, Gatton, Queensland, Australia 4343

†Present address: Department of Animal Science, Texas A\&M University, College Station, TX 77843-2471, USA

\$Present address: University Outreach and Extension, University of Missouri, 299 East Second St., Lebanon, MO 65536, USA

`Correspondence

Email: kinder.15@osu.edu
}

pituitary desensitization is characterized by decreased gonadotrophin secretion and reduced responsiveness to further GnRH stimulation. Pituitary desensitization to $\mathrm{GnRH}$ and the resulting decrease of $\mathrm{LH}$ concentration in blood induces impairment of gonadal function, which can eventually lead to azoospermia and infertility (Labrie et al., 1980; Bint Akhtar et al., 1983; Vickery et al., 1985). Cattle appear less sensitive to the negative effects of chronic administration of GnRH (Melson et al., 1986; Ronayne et al., 1993; D'Occhio and Aspden, 1996). For example, chronic treatment with $\mathrm{GnRH}$ or $\mathrm{GnRH}$ agonist in bulls is associated with enhanced testicular function, as evidenced by increased concentrations of testosterone in the blood (Melson et al., 1986; Ronayne et al., 1993; D'Occhio and Aspden, 1996), greater testicular size (D'Occhio and Aspden, 1996; Aspden et al., 1998), increased numbers of testicular LH receptors (Melson et al., 1986) and enhanced steroidogenic and spermatogenic capacities (Aspden et al., 1998). Paradoxically, increased steroidogenic capacity occurs in bulls treated with agonist even though bulls have 
a classical downregulation of the pituitary gland. Downregulation of the pituitary gland is associated with a lack of responsiveness to exogenous $\mathrm{GnRH}$ stimulation (Melson et al., 1986; D'Occhio and Aspden, 1996), decreased numbers of GnRH receptors (Melson et al., 1986), lower pituitary content of LH and FSH (Melson et al., 1986; Aspden et al., 1996) and lower amounts of LH- $\beta$ and FSH- $\beta$ subunit mRNA (Aspden et al., 1996, 1997). Similarly, female cattle treated with GnRH agonist show enhanced luteal function (Davis et al., 2000) and have increased blood concentrations of progesterone (Gong et al., 1995; Davis et al., 2000) and oestradiol (Bergfeld et al., 1996a).

The mechanism(s) whereby agonists induce functional and morphological changes in the testes of bulls is not known. It is possible that the apparent enhancement of testicular function in bulls treated with $\mathrm{GnRH}$ agonist may result from changes in $\mathrm{LH}$ status, including alterations in basal secretion, characteristics of pulsatile secretion or mean plasma concentrations. A lack of pulsatile secretion of $\mathrm{LH}$ in cattle during agonist treatment has been associated with normal (Melson et al., 1986; Ronayne et al., 1993; Bergfeld et al., 1996a,b) or slightly higher (Gong et al., 1995; D'Occhio and Aspden, 1996) than normal mean plasma concentrations of LH. The sampling frequencies in these studies unfortunately did not allow a precise description of individual components of the $\mathrm{LH}$ secretory profile. Accordingly, the primary aim of the present study was to provide a thorough description of the characteristics of $\mathrm{LH}$ secretion in bulls treated with $\mathrm{GnRH}$ agonist. This information is fundamental to understanding the biological basis for increased steroidogenic function in bulls treated with GnRH agonist that have a downregulated pituitary gland. It is hypothesized that chronic treatment with GnRH agonist in bulls results in increased basal concentrations of $\mathrm{LH}$ in the blood and that this provides the basis for increased testicular LH receptors and greater steroidogenic function. Changes in FSH secretion were also monitored in order to obtain a complete understanding of the characteristics of gonadotrophin secretion in male cattle during treatment with GnRH agonist.

\section{Materials and Methods}

\section{Experimental animals}

All protocols and procedures used in this experiment were approved by the Institutional Animal Care and Use Committee at the University of Nebraska, Lincoln. Eighteen bull calves (1/4 Hereford, 1/4 Angus, 1/4 Pinzgauer, 1/4 Red Poll) were used. At the beginning of the experiment, bull calves averaged $152 \pm$ 0.6 days of age, and $182 \pm 3.1 \mathrm{~kg}$ body weight (BW). The GnRH agonist used was azagly-nafarelin ([D-Nal $(2)^{6}$, aza-Gly $\left.{ }^{10}\right] \mathrm{GnRH}$; Intervet International BV, Boxmeer).

\section{Treatments}

Bulls were randomly allotted to three groups and each group was assigned to one of three treatments ( $n=6$ bulls per group) as follows: a placebo group treated with the vehicle (control), or treated with a relatively small $\left(1 \mu \mathrm{g} \mathrm{kg}^{-1} \mathrm{BW} \mathrm{day}^{-1} ; \mathrm{A} 1\right)$ or a relatively large (3 $\mathrm{g} \mathrm{kg}^{-1}$ BW day $^{-1}$; A3) dose of azagly-nafarelin. This GnRH agonist is considered to be 200 times more potent than the native GnRH in rats. The large dose of azagly-nafarelin was similar in potency to a similar GnRH agonist used in previous studies with young bulls (Ronayne et al., 1993). The vehicle used was 5\% $(\mathrm{w} / \mathrm{v})$ mannitol diluted in distilled water. Treatments were administered subcutaneously via an Alzet mini-osmotic pump (model 2ML4; Alza Corp., Palo Alto, CA) for 28 days. Pumps were inserted beneath the skin overlying the ribs, under local anaesthetic. Before insertion, pumps were pre-incubated overnight in $0.15 \mathrm{~mol}$ sodium chloride $\mathrm{I}^{-1}$ at $37^{\circ} \mathrm{C}$, to ensure an immediate release of the hormone after insertion of the pumps.

\section{Blood sampling}

Blood samples were taken every $2 \mathrm{~h}$ from 2 to $20 \mathrm{~h}$ after inserting the pumps. At the end of this period, serial blood samples $(5 \mathrm{ml})$ were collected every $20 \mathrm{~min}$ for $24 \mathrm{~h}$ (day 2). Additional serial blood samplings were made on days 13 and 25 of the treatment period. Animals were fitted with indwelling jugular catheters ${ }^{\circledR}$ (Tygon flexible plastic tubing, ID: $1.27 \mathrm{~mm}$, OD: $2.29 \mathrm{~mm}$; Norton Performance Plastics, Akron, $\mathrm{OH}$ ) one day before the start of each collection period. Blood samples were allowed to clot at room temperature and were then stored at $4{ }^{\circ} \mathrm{C}$. Blood was centrifuged within $36 \mathrm{~h}$ of collection at $1500 \mathrm{~g}$ for $20 \mathrm{~min}$ at $4^{\circ} \mathrm{C}$. Serum was then decanted into polypropylene vials and stored at $-20^{\circ} \mathrm{C}$ until assayed for $\mathrm{LH}, \mathrm{FSH}$ and testosterone concentrations.

\section{Hormone radioimmunoassays}

Concentrations of $\mathrm{LH}$ were determined in all samples by a double-antibody radioimmunoassay (Wolfe et al., 1989). The limit of detection was $140 \mathrm{pg} \mathrm{ml}^{-1}$. The intraand inter-assay coefficients of variation (CV) were 4.8 and $6.6 \%$, respectively. Concentrations of FSH were determined in selected samples (every $2 \mathrm{~h}$ ) from the serial blood sampling periods and in all the other samples collected during the experiment. Determinations were made by a double-antibody radioimmunoassay (Wolfe et al., 1989). The limit of detection was $154 \mathrm{pg} \mathrm{ml}^{-1}$. The intraand inter-assay CVs were 2.4 and $3 \%$, respectively.

Concentrations of testosterone were determined in every other serial sample that was collected, and in all the other samples collected during the experiment. Duplicate $25 \mu \mathrm{l}$ aliquots of sample were double-extracted with ether, and extract residues were 
re-suspended in $600 \mu \mathrm{l}$ Tris-buffered saline with $0.1 \%$ $(\mathrm{w} / \mathrm{v})$ gelatin (TBS-gel), to be assayed by a doubleantibody radioimmunoassay, using a micro-scale method for liquid scintillation counting (Grotjan and Steinberg, 1978). The assay used a sheep anti-T antibody (GDN no. 250; $200 \mu \mathrm{l}$ of a 1:120000 dilution), provided by G. Niswender (Colorado State University, Fort Collins, $\mathrm{CO}), \quad\left[1,2,6,7-{ }^{3} \mathrm{H}(\mathrm{N})\right]$ testosterone (24 000 d.p.m per tube; New England Nuclear, Boston, MA); and donkey anti-sheep gamma globulin (DSG 1002; 200 $\mu$ l of a 1:55 dilution; ImmunoVision, Springdale, AR) as second antibody. The standard curve was prepared with testosterone in solution with ethanol (3.6-461.4 pg $\left.(25 \mu \mathrm{l})^{-1}\right)$, allowed to dry and re-suspended in TBS gel. The limit of detection was $50 \mathrm{pg} \mathrm{ml}^{-1}$. The intra- and inter-assay CVs were 4.4 and $7.9 \%$, respectively.

The validation of the radioimmunoassay for testosterone was as follows. Fifteen different bull serum samples were assayed at 10, 20 and $40 \mu \mathrm{l}$. These serial dilutions generated binding inhibition curves that paralleled the testosterone standard curve. Furthermore, the average ratios $\pm \mathrm{SD}$ and correlations of the testosterone concentrations obtained between the different pairs of volumes were $0.94 \pm 0.13(r=0.996), 0.99 \pm 0.11(r=0.99)$ and $0.93 \pm 0.17(r=0.995)$ respectively, for 10 versus $20 \mu \mathrm{l}, 20$ versus $40 \mu \mathrm{l}$ and 10 versus $40 \mu \mathrm{l}$. Three bovine serum samples were used to evaluate recovery of mass. Different amounts of added testosterone were utilized (50, 100, 200, 400 and 800 pmol per tube), and the average \pm SD recovery from these samples was $97 \pm 3.9 \%$.

\section{Hormone secretory pattern and statistical analyses}

Secretory patterns of $\mathrm{LH}$ and testosterone were evaluated for mean and basal concentration and for pulse frequency and amplitude, using computerized algorithms (Merriam and Wachter, 1982; Pulsar software modified for IBM-PC by J. F. Gitzen and V. D. Ramirez). This method removes long-term trends, such as diurnal rhythms, from the series of observations and calculates a base line by generating a smoothed series that omits peaks or trends with time constants less than 6 to $12 \mathrm{~h}$. It identifies peaks by criteria of both height and duration of deviation from the base line, measured relative to the expected random variability of the series. The smoothing time was set to $12 \mathrm{~h}$. The assay standard deviation used in the algorithm was modelled as a quadratic function of the dose for each hormone. $G$ values used were: $G(1)=$ 3.8, $G(2)=2.6, G(3)=1.9, G(4)=1.5$ and $G(5)=1.2$.

Data for LH and testosterone secretory patterns, and mean concentrations of FSH on days 2, 13 and 25 of the treatment were analysed as a completely randomized design, using the MIXED procedure of SAS (Littell et al., 1996) with the statement repeated, the options sub = animal (treatment), and autoregressive (1) covariance structure within animal. Treatment, day, and treatment- (a)

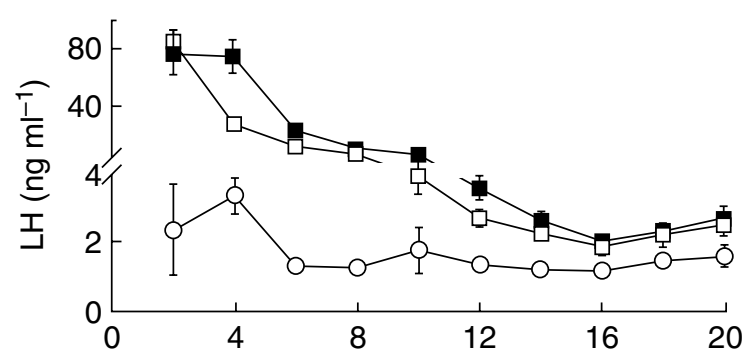

(b)

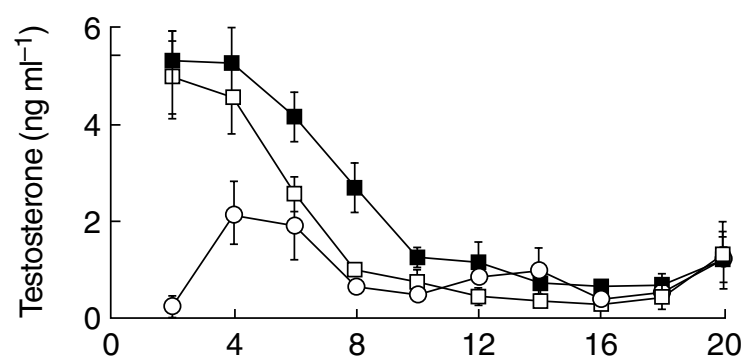

(c)

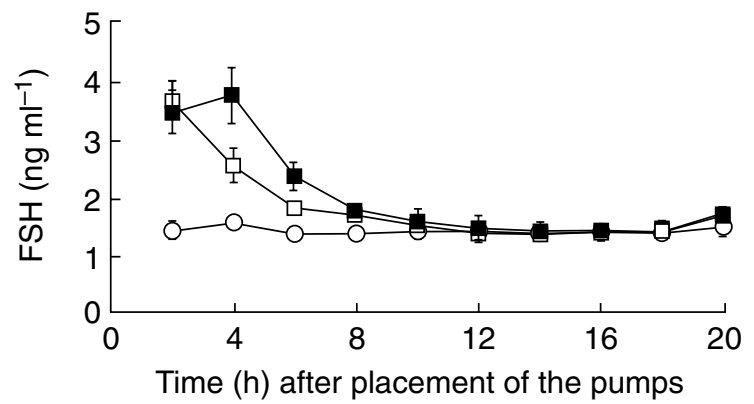

Fig. 1. Mean ( $\pm \mathrm{SE}$ ) serum concentrations of (a) $\mathrm{LH}$, (b) testosterone and (c) FSH in prepubertal bulls from 2 to $20 \mathrm{~h}$ after insertion of the pumps. Bulls were treated with vehicle (control; $\bigcirc$ ), or with a small $\left(1 \mu \mathrm{g} \mathrm{kg}^{-1}\right.$ body weight (BW) day $\left.{ }^{-1} ; \mathrm{A} 1: \square\right)$, or large $(3 \mu \mathrm{g}$ $\left.\mathrm{kg}^{-1} \mathrm{BW} \mathrm{day}^{-1} ; \mathrm{A} 3: \mathbf{0}\right)$ dose of the GnRH agonist azagly-nafarelin for 28 days.

by-day interaction were included in the model. The PDIFF option of SAS was used to compare least square means among treatments. Except for FSH concentration, all variables were $\log _{10}(Y+1)$ transformed so as to be consistent with the assumptions of the ANOVA.

\section{Results}

Response to GnRH agonist during the initial $20 \mathrm{~h}$ of treatment

Hormonal concentrations in bulls from 2 to $20 \mathrm{~h}$ after insertion of the mini-osmotic pumps are shown (Fig. 1). Two hours after insertion of the pumps, concentrations of $\mathrm{LH}$ (Fig. 1a) reached $84.49 \pm 7.99$ and $77.19 \pm$ $15.23 \mathrm{ng} \mathrm{ml}^{-1}$, respectively, for groups A1 and A3, compared with $2.33 \pm 1.33$ for the control group. Thereafter, $\mathrm{LH}$ concentrations decreased in both groups to values 
Table 1. Average ( \pm SEM) characteristics for LH secretory patterns in prepubertal bulls on days 2,13 and 25 of treatment

\begin{tabular}{|c|c|c|c|c|c|}
\hline $\begin{array}{l}\text { Day of } \\
\text { treatment }\end{array}$ & Treatment* & $\begin{array}{c}\text { Mean } \\
\left(\mathrm{ng} \mathrm{ml}^{-1}\right)\end{array}$ & $\begin{array}{c}\text { Basal } \\
\left(\mathrm{ng} \mathrm{ml}^{-1}\right)\end{array}$ & $\begin{array}{l}\text { Pulse frequency } \\
\text { (pulses } 24 \mathrm{~h}^{-1} \text { ) }\end{array}$ & $\begin{array}{l}\text { Pulse amplitude } \\
\quad\left(\mathrm{ng} \mathrm{ml}^{-1}\right)\end{array}$ \\
\hline 2 & $\begin{array}{l}\text { Control } \\
\text { A1 } \\
\text { A3 }\end{array}$ & $\begin{array}{l}1.67 \pm 0.21^{\mathrm{e}} \\
2.36 \pm 0.28^{\mathrm{d}} \\
2.76 \pm 0.32^{\mathrm{d}}\end{array}$ & $\begin{array}{l}0.99 \pm 0.12^{\mathrm{b}} \\
2.35 \pm 0.27^{\mathrm{a}} \\
2.74 \pm 0.32^{\mathrm{a}}\end{array}$ & $\begin{array}{l}3.00 \pm 1.00^{\mathrm{a}} \\
0.00^{\mathrm{b}} \\
0.00^{\mathrm{b}}\end{array}$ & $\begin{aligned} 10.11 & \pm 3.15 \\
& - \\
& -\end{aligned}$ \\
\hline 13 & $\begin{array}{l}\text { Control } \\
\text { A1 } \\
\text { A3 }\end{array}$ & $\begin{array}{l}1.60 \pm 0.19 \\
1.75 \pm 0.08 \\
1.47 \pm 0.09\end{array}$ & $\begin{array}{l}0.75 \pm 0.07^{\mathrm{b}} \\
1.70 \pm 0.07^{\mathrm{a}} \\
1.44 \pm 0.08^{\mathrm{a}}\end{array}$ & $\begin{array}{l}4.33 \pm 0.84^{\mathrm{a}} \\
0.17 \pm 0.17^{\mathrm{b}} \\
0.17 \pm 0.17^{\mathrm{b}}\end{array}$ & $\begin{array}{c}7.35 \pm 1.36 \\
3.16^{\ddagger} \\
0.84^{\ddagger}\end{array}$ \\
\hline 25 & $\begin{array}{l}\text { Control } \\
\text { A1 } \\
\text { A3 }\end{array}$ & $\begin{array}{l}1.14 \pm 0.24 \\
1.29 \pm 0.06 \\
1.17 \pm 0.16\end{array}$ & $\begin{array}{l}0.62 \pm 0.11^{\mathrm{e}} \\
1.28 \pm 0.06^{\mathrm{d}} \\
1.10 \pm 0.12^{\mathrm{d}}\end{array}$ & $\begin{array}{c}1.83 \pm 0.65^{\mathrm{d} \dagger} \\
0.00^{\mathrm{e}} \\
0.67 \pm 0.42^{\mathrm{de} \dagger}\end{array}$ & $\begin{array}{c}8.63 \pm 0.85 \\
- \\
1.99 \pm 1.17\end{array}$ \\
\hline Overall & $\begin{array}{l}\text { Control } \\
\text { A1 } \\
\text { A3 }\end{array}$ & $\begin{array}{l}1.47 \pm 0.13 \\
1.80 \pm 0.14 \\
1.80 \pm 0.20\end{array}$ & $\begin{array}{l}0.79 \pm 0.07^{\mathrm{b}} \\
1.78 \pm 0.14^{\mathrm{a}} \\
1.76 \pm 0.20^{\mathrm{a}}\end{array}$ & $\begin{array}{l}3.06 \pm 0.52^{\mathrm{a}} \\
0.06 \pm 0.06^{\mathrm{b}} \\
0.28 \pm 0.16^{\mathrm{b}}\end{array}$ & $\begin{array}{c}8.61 \pm 1.16 \\
3.16^{\ddagger} \\
1.61^{\ddagger}\end{array}$ \\
\hline
\end{tabular}

*Bulls were treated with vehicle (control), or with a small $\left(1 \mu \mathrm{g} \mathrm{kg}{ }^{-1}\right.$ body weight (BW) day ${ }^{-1}$; A1) or large $\left(3 \mu \mathrm{g} \mathrm{kg}{ }^{-1} \mathrm{BW} \mathrm{day}^{-1}\right.$; $\left.\mathrm{A} 3\right)$ dose of the GnRH agonist azagly-nafarelin for 28 days.

${ }^{\dagger}$ Any two means with a dagger for the same variable and day tend to be different from each other $(P<0.10)$, but the effect is not significant.

¥The standard error could not be calculated.

Means with different superscripts within variable and day are different: ${ }^{\mathrm{a}, \mathrm{b}} P<0.001$; ${ }^{\mathrm{d}, \mathrm{e}} P<0.05$.

comparable to control animals by $18 \mathrm{~h} \quad(1.32 \pm$ $0.25 \mathrm{ng} \mathrm{ml}^{-1}$ ). Testosterone concentrations (Fig. 1b) followed a similar pattern to $\mathrm{LH}$ in both agonist-treated groups, with values of $4.99 \pm 0.76 \mathrm{ng} \mathrm{ml}^{-1}$ (A1) and $5.2 \pm 1.1 \mathrm{ng} \mathrm{ml}^{-1}$ (A3) $2 \mathrm{~h}$ after insertion of the pumps, decreasing to values similar to the control group between $6 \mathrm{~h}\left(2.55 \pm 0.37 \mathrm{ng} \mathrm{ml}^{-1}\right.$ for group $\left.\mathrm{A} 1\right)$ and $12 \mathrm{~h}$ $\left(1.09 \pm 0.42 \mathrm{ng} \mathrm{ml}^{-1}\right.$ for group A3) after insertion of the pumps. Concentrations of FSH (Fig. 1c) reached $3.69 \pm 0.34 \mathrm{ng} \mathrm{ml}^{-1}$ by $2 \mathrm{~h}$ in group $\mathrm{A} 1$, and $3.77 \pm$ $0.48 \mathrm{ng} \mathrm{ml}^{-1}$ by $4 \mathrm{~h}$ in group A3. Concentrations of $\mathrm{FSH}$ then decreased to values similar to the control group $\left(1.58 \pm 0.11 \mathrm{ng} \mathrm{ml}^{-1}\right)$.

\section{Characteristics of the $\mathrm{LH}$ secretory patterns on days 2, 13 and 25 of treatment}

Characteristics of the $\mathrm{LH}$ patterns during the three $24 \mathrm{~h}$ sampling periods are shown (Table 1). The interaction of treatment by day was significant for mean LH concentration $(P<0.05)$. Both agonist-treated groups had higher $(P<0.05)$ mean concentrations of $\mathrm{LH}$, compared with the control group on day 2 only. The overall effect of treatment on mean $\mathrm{LH}$ concentration was not significant.

For basal concentration of $\mathrm{LH}$, the effects of treatment $(P<0.001)$ and treatment-by-day interaction $(P<0.05)$ were significant. During the three periods of sampling, both agonist-treated groups had higher $(P<0.05)$ basal concentrations of $\mathrm{LH}$ compared with the control group. The overall basal concentrations of $\mathrm{LH}$ in groups $\mathrm{A} 1$ and $\mathrm{A} 3$ were $1 \mathrm{ng} \mathrm{ml}^{-1}$ above the values detected in the control group $(P<0.001)$.
The interaction of treatment by day was significant $(P<0.05)$ for frequency of LH pulses. No LH pulses were detected in almost all bulls treated with the GnRH agonist during the three sampling periods. In group A1, only one bull had one pulse during the sampling on day 13 . In group A3, one bull had two pulses on day 25 , and another bull had one pulse on day 13 and two pulses on day 25. During the three periods of sampling and overall, pulse frequency was less $(P<0.001)$ in both agonist-treated groups compared with the control group.

Owing to the small number of pulses of $\mathrm{LH}$ in the agonist-treated groups, on some days the standard error for pulse amplitude could not be calculated and it was not possible to make statistical comparisons among treatments; therefore, only numerical data for this variable are included (Table 1). Individual $\mathrm{LH}$ and testosterone secretory patterns from one bull of each group on day 13 of treatment are shown (Fig. 2). Basal concentrations of $\mathrm{LH}$ and testosterone were higher in both groups treated with the GnRH agonist (Fig. 2b,c) compared with the control group. Patterns of LH and testosterone secretory episodes also differed between control and agonist-treated bulls. In control bulls (Fig. 2a), LH pulses were characterized by a sharp increase, followed by a gradual decrease until returning to basal values; in addition, a pulse of testosterone usually followed each pulse of LH. In contrast, the few pulses of $\mathrm{LH}$ detected in bulls treated with the GnRH agonist (Fig. 2c) were of small amplitude, had a longer period to reach the peak and return to basal concentrations, and were not clearly associated with subsequent increases of testosterone. 
Characteristics of testosterone secretory patterns on days 2, 13 and 25 of treatment

Treatment with both doses of GnRH agonist either tended to increase $(P<0.10)$ or increased significantly $(P<0.05)$ mean concentration of testosterone at each day of sampling and overall (Table 2) compared with the control group, except on day 13, when mean concentrations of testosterone were similar in group $\mathrm{A} 3$ and the control group $(P>0.10)$. Bulls in group $\mathrm{A} 1$ tended to have higher mean concentrations of testosterone compared with those in group $\mathrm{A} 3$ on day $13(P=0.09)$, although the effect was not significant, and had higher mean testosterone concentrations on day $25(P<0.05)$. Basal testosterone concentration was higher $(P<0.05)$ in both agonist-treated groups compared with the control group at each day of sampling. Furthermore, the overall basal concentration of testosterone was higher $(P<0.05)$ in groups A1 (12-fold) and A3 (8-fold) compared with the control group. Bulls in group A1 tended to have higher basal concentrations of testosterone compared with those in group A3 on day $13(P=0.07)$ and had higher basal concentrations on day $25(P<0.05)$.

Treatment with both doses of $\mathrm{GnRH}$ agonist reduced $(P<0.05)$ the number of testosterone pulses in the $24 \mathrm{~h}$ sampling periods, except for group A3 at day 25 . Agonist-treated groups were different from each other in number of testosterone pulses only on day $25(P<0.05)$. Most testosterone pulses in the agonist-treated bulls differed in shape compared with the bulls in the control group, in a way similar to that described for $\mathrm{LH}$ pulses (Fig. 2). A detectable pulse of LH did not always precede pulses of testosterone in these groups. Considering the apparent absence of $\mathrm{LH}$ pulses preceding testosterone, it was unclear whether the increases in testosterone were induced by release of $\mathrm{LH}$, or were sustained increases of testosterone responding to the constantly higher basal concentrations of LH. Owing to the few pulses of testosterone in the agonist-treated groups, on some days the standard error for pulse amplitude could not be calculated and it was not possible to make statistical comparisons among treatments; therefore, only numerical data for this variable are included (Table 2).

\section{Concentrations of FSH on days 2, 13 and 25 of treatment}

Data for mean concentration of $\mathrm{FSH}$ are shown (Table 3). The effects of treatment and treatment-by-day interaction were significant $(P<0.05)$. Bulls treated with the small dose of $\mathrm{GnRH}$ agonist tended to have increased $(P=0.08)$ FSH concentrations compared with the control group on day 13 , and had higher FSH concentrations on days 2,25 and overall $(P<0.05)$. Overall concentration of FSH tended ( $P=0.08)$ to be higher in group $\mathrm{A} 3$, and was higher on days 2 and $25(P<0.05)$ compared with the control group. (a)

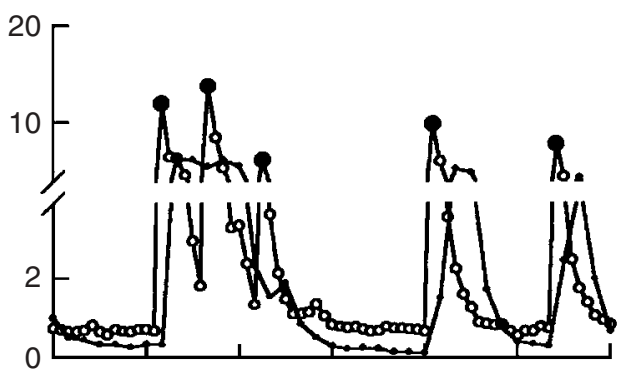

(b)

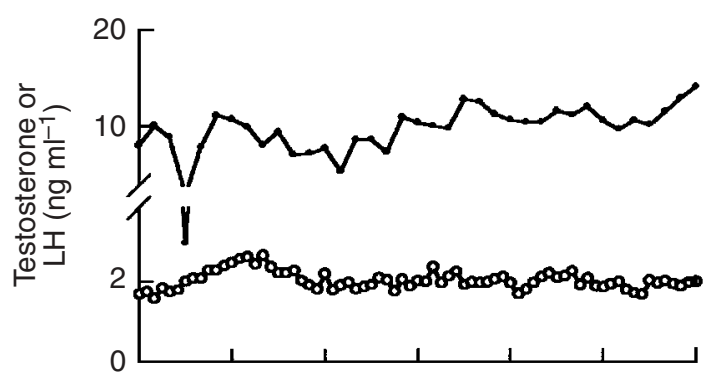

(c)

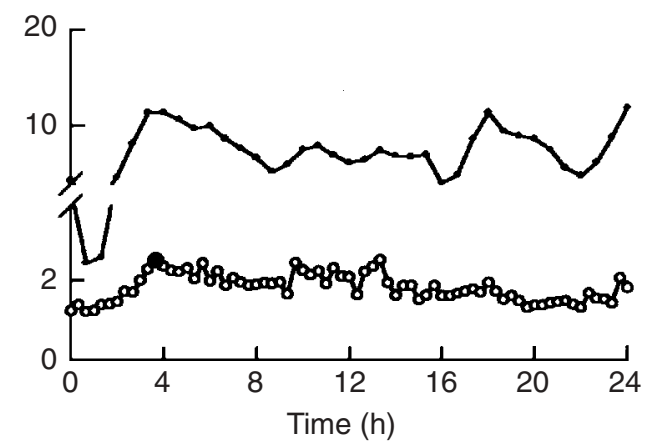

Fig. 2. Individual secretory patterns of LH and testosterone in prepubertal bulls on day 13 of treatment. Bulls were treated with (a) vehicle (control), or with (b) a small $\left(1 \mu \mathrm{g} \mathrm{kg}^{-1}\right.$ body weight (BW) day $\left.^{-1}\right)$ or (c) a large $\left(3 \mu \mathrm{g} \mathrm{kg}^{-1} \mathrm{BW} \mathrm{day}^{-1}\right)$ dose of the GnRH agonist azagly-nafarelin for 28 days. Samples were taken every $20 \mathrm{~min}$ (LH) or every $40 \mathrm{~min}$ (testosterone) for $24 \mathrm{~h}$, starting at 08:00 h. Open circles denote $\mathrm{LH}$ concentration, small black circles denote testosterone concentration and large black circles denote detected LH pulses.

\section{Discussion}

The most significant finding in the present study was a clear and consistent increase in basal concentration of $\mathrm{LH}$ in bulls treated with the GnRH agonist, azaglynafarelin, regardless of the dose used. Although Ronayne et al. (1993) reported a small increase in basal concentration of $\mathrm{LH}$ in $\mathrm{GnRH}$ agonist-treated bulls, this increase was observed only during the first day of treatment and not on subsequent days. Furthermore, Melson et al. (1986) suggested an increase in basal LH concentration in bulls treated with nafarelin acetate, but this action 
Table 2. Average $( \pm$ SEM) characteristics for testosterone secretory patterns in prepubertal bulls on days 2, 13 and 25 of treatment

\begin{tabular}{|c|c|c|c|c|c|}
\hline $\begin{array}{l}\text { Day of } \\
\text { treatment }\end{array}$ & Treatment* & $\begin{array}{c}\text { Mean } \\
\left(\mathrm{ng} \mathrm{ml}^{-1}\right)\end{array}$ & $\begin{array}{c}\text { Basal } \\
\left(\mathrm{ng} \mathrm{ml}^{-1}\right)\end{array}$ & $\begin{array}{l}\text { Pulse frequency } \\
\text { (pulses } 24 \mathrm{~h}^{-1} \text { ) }\end{array}$ & $\begin{array}{l}\text { Pulse amplitude } \\
\quad\left(\mathrm{ng} \mathrm{m}^{-1}\right)\end{array}$ \\
\hline 2 & $\begin{array}{l}\text { Control } \\
\text { A1 } \\
\text { A3 }\end{array}$ & $\begin{array}{l}0.79 \pm 0.16^{\mathrm{e} \dagger} \\
2.44 \pm 0.82^{\mathrm{de} \dagger} \\
2.76 \pm 0.83^{\mathrm{d}}\end{array}$ & $\begin{array}{l}0.40 \pm 0.07^{\mathrm{e}} \\
2.45 \pm 0.82^{\mathrm{d}} \\
2.76 \pm 0.84^{\mathrm{d}}\end{array}$ & $\begin{array}{l}2.67 \pm 0.88^{\mathrm{d}} \\
0.17 \pm 0.17^{\mathrm{e}} \\
0.17 \pm 0.17^{\mathrm{e}}\end{array}$ & $\begin{array}{c}2.76 \pm 0.64 \\
1.18^{\ddagger} \\
0.77^{\ddagger}\end{array}$ \\
\hline 13 & $\begin{array}{l}\text { Control } \\
\text { A1 } \\
\text { A3 }\end{array}$ & $\begin{array}{l}1.64 \pm 0.39^{\mathrm{e}} \\
6.35 \pm 1.52^{\mathrm{d} \dagger} \\
3.88 \pm 1.31^{\mathrm{de} \dagger}\end{array}$ & $\begin{array}{l}0.47 \pm 0.10^{\mathrm{e}} \\
5.98 \pm 1.45^{\mathrm{d} \dagger} \\
3.57 \pm 1.18^{\mathrm{d} \dagger}\end{array}$ & $\begin{array}{l}3.67 \pm 0.71^{\mathrm{d}} \\
1.00 \pm 0.37^{\mathrm{e}} \\
1.00 \pm 0.45^{\mathrm{e}}\end{array}$ & $\begin{array}{l}4.89 \pm 0.95 \\
4.08 \pm 1.30 \\
2.56 \pm 1.28\end{array}$ \\
\hline 25 & $\begin{array}{l}\text { Control } \\
\text { A1 } \\
\text { A3 }\end{array}$ & $\begin{array}{l}1.35 \pm 0.43^{\mathrm{e}^{\dagger}} \\
7.54 \pm 1.04^{\mathrm{d}} \\
3.76 \pm 1.32^{\mathrm{e} \dagger}\end{array}$ & $\begin{array}{l}0.45 \pm 0.07^{f} \\
7.54 \pm 1.03^{d} \\
3.68 \pm 1.34^{e}\end{array}$ & $\begin{array}{l}2.00 \pm 0.68^{d} \\
0.17 \pm 0.17^{e} \\
1.17 \pm 0.31^{d}\end{array}$ & $\begin{array}{c}6.08 \pm 1.67 \\
1.69^{\ddagger} \\
1.73 \pm 0.47\end{array}$ \\
\hline Overall & $\begin{array}{l}\text { Control } \\
\text { A1 } \\
\text { A3 }\end{array}$ & $\begin{array}{l}1.26 \pm 0.21^{\mathrm{e} \dagger} \\
5.45 \pm 0.82^{\mathrm{d}} \\
3.47 \pm 0.65^{\mathrm{de} \dagger}\end{array}$ & $\begin{array}{l}0.44 \pm 0.04^{\mathrm{e}} \\
5.32 \pm 0.80^{\mathrm{d}} \\
3.34 \pm 0.62^{\mathrm{d}}\end{array}$ & $\begin{array}{l}2.78 \pm 0.45^{\mathrm{d}} \\
0.44 \pm 0.17^{\mathrm{e}} \\
0.78 \pm 0.21^{\mathrm{e}}\end{array}$ & $\begin{array}{l}4.57 \pm 0.69 \\
2.90 \pm 0.10 \\
0.93 \pm 0.56\end{array}$ \\
\hline
\end{tabular}

*Bulls were treated with vehicle (control), or with a small $\left(1 \mu \mathrm{g} \mathrm{kg}{ }^{-1}\right.$ body weight (BW) per day; A1) or large $\left(3 \mu \mathrm{g} \mathrm{kg}{ }^{-1} \mathrm{BW}\right.$ per day; A3) dose of the GnRH agonist azagly-nafarelin for 28 days.

${ }^{\dagger}$ Any two means with a dagger for the same variable and day tend to be different from each other $(P<0.10)$, but the effect is not significant.

¥The standard error could not be calculated.

Means with different superscripts within variable and day are different: ${ }^{\mathrm{d}, \mathrm{e}, \mathrm{f}} P<0.05$.

Table 3. Mean concentrations $( \pm \mathrm{SEM})$ of $\mathrm{FSH}\left(\mathrm{ng} \mathrm{ml}^{-1}\right)$ in prepubertal bulls on days 2,13 and 25 of treatment

\begin{tabular}{lcccc}
\hline & \multicolumn{3}{c}{ Day of treatment } \\
\cline { 2 - 4 } Treatment* & Day 2 & Day 13 & Day 25 & Overall \\
\hline Control & $1.30 \pm 0.05^{\mathrm{e}}$ & $1.22 \pm 0.11^{\mathrm{h}}$ & $1.11 \pm 0.11^{\mathrm{e}}$ & $1.21 \pm 0.05^{\mathrm{e} \dagger}$ \\
A1 & $1.64 \pm 0.08^{\mathrm{d}}$ & $1.48 \pm 0.14^{\mathrm{g}}$ & $1.51 \pm 0.12^{\mathrm{d}}$ & $1.54 \pm 0.07^{\mathrm{d}}$ \\
A3 & $1.67 \pm 0.08^{\mathrm{d}}$ & $1.21 \pm 0.08^{\mathrm{h}}$ & $1.39 \pm 0.09^{\mathrm{d}}$ & $1.42 \pm 0.06^{\mathrm{de} \dagger}$ \\
\hline
\end{tabular}

*Bulls were treated with vehicle (control), or with a small $\left(1 \mu \mathrm{gg}^{-1}\right.$ body weight (BW) day ${ }^{-1}$; A1) or large $\left(3 \mu \mathrm{g} \mathrm{kg}{ }^{-1}\right.$ BW day $^{-1}$; A3) dose of the GnRH agonist azagly-nafarelin for 28 days.

${ }^{\dagger}$ Any two means with a dagger in the same day tend to be different from each other $(P<0.10)$, but the effect is not significant.

Means with different superscripts within day are different or tend to be different: ${ }^{\mathrm{d}, \mathrm{e}} P<0.05$; ${ }^{\mathrm{g}, \mathrm{h}} P<0.10$.

of the GnRH agonist was not clearly shown. Therefore, previous studies have shown inconsistent effects of the $\mathrm{GnRH}$ agonists on LH concentration. The schedule of sampling used in the present study (every $20 \mathrm{~min}$ for $24 \mathrm{~h}$ ) allows for a more accurate characterization of the LH secretory patterns, compared with single samples per day or serial samplings made in shorter periods of time, as used in previous studies. In the present study, the increased basal concentration of $\mathrm{LH}$ in the agonisttreated bulls was more marked at day 2 of treatment (137$176 \%$ above the basal concentration in control bulls). At days 13 and 25, basal LH in agonist-treated groups was still $77-100 \%$ above the values detected in control animals, indicating that increased basal concentrations of $\mathrm{LH}$ in bulls chronically treated with the $\mathrm{GnRH}$ agonist can be maintained over extended periods of time.

The reduced number or the lack of $\mathrm{LH}$ pulses in bulls treated with $\mathrm{GnRH}$ agonists has been previously reported (Melson et al., 1986; Ronayne et al., 1993; D'Occhio and Aspden, 1996). Given that endogenous pulses of
$\mathrm{GnRH}$ are not suppressed by chronic treatment with the GnRH agonist (Caraty et al., 1990), the suppression of LH pulses indicates that the pituitary gland of cattle becomes desensitized to endogenous GnRH pulses, similar to the response in other species. Pituitary desensitization is supported by findings in a related study in which bulls treated with a GnRH agonist failed to respond to exogenous administration of natural sequence $\mathrm{GnRH}$, or did not present the classical LH increase after castration (D'Occhio and Aspden, 1996).

Another possibility is that the treatment with the GnRH agonist changes the pulsatile pattern of $\mathrm{LH}$, from a lesser frequency and greater amplitude similar to that found in the control bulls, to a greater frequency and lesser amplitude pattern of LH secretion. If this had occurred, pulses might not have been detected by the method used, and basal LH would have been over-estimated. However, it is unlikely that this is the situation. The algorithm used to analyse the $\mathrm{LH}$ episodes makes no assumptions about ideal peak shapes. Instead, it requires that peaks 
have some combination of height and width. A peak is detected if it is of great amplitude, even if it is narrow, or if it has moderate amplitude, but extends for several points in width (Merriam and Wachter, 1982). Furthermore, in the authors' experience, this method has been able to detect $\mathrm{LH}$ pulses with amplitudes of $0.25 \mathrm{ng} \mathrm{ml}^{-1}$.

In the present study, and in previous studies (Melson et al., 1986; Ronayne et al., 1993; Bergfeld et al., 1996b; D'Occhio and Aspden, 1996), bulls chronically treated with GnRH agonists have increased concentrations of testosterone in the blood. The reasons for greater concentrations of testosterone when $\mathrm{LH}$ pulses are essentially not occurring and when mean LH concentration appears to be normal are unclear. Results from the present experiment and data reported by others (Chase et al., 1988; Mendis-Handagama et al., 1998) support the hypothesis that the enhanced testicular steroidogenesis and increased blood concentrations of testosterone most likely result from the increased basal concentration of $\mathrm{LH}$ in bulls chronically treated with $\mathrm{GnRH}$ agonist. Previous studies in rams immunized against $\mathrm{GnRH}$ and treated with $\mathrm{LH}$ for 12 to 20 days indicate that the infusion of $\mathrm{LH}$ producing the highest basal concentration of $\mathrm{LH}$ also resulted in the greatest testosterone response to $\mathrm{LH}$ administration (Chase et al., 1988). In adult rats, continuous infusion of LH for 2 weeks induced hypertrophy and hyperplasia of Leydig cells, associated with a sixfold increase in testosterone secretory capacity, with no change in testis volume (MendisHandagama et al., 1998). Moreover, chronic treatment of intact rats with LH or hCG results in increased capacity for LH-stimulated testosterone production and induction of steroidogenic enzyme synthesis (Payne et al., 1980; O'Shaughnessy and Payne, 1982). Signs of enhanced steroidogenesis are also reported for bulls treated for 10 days with implants of the $\mathrm{GnRH}$ agonist deslorelin (Aspden et al., 1998). The testes of these bulls had increased amounts of StAR protein and the steroidogenic enzymes $\mathrm{P}_{450} 0_{\text {scc }}$ and $3 \beta$-hydroxysteroid dehydrogenase, and $17 \alpha$-hydroxylase mRNA, indicating increased testicular stimulation by $\mathrm{LH}$, because the synthesis of these enzymes is stimulated by LH (Saez, 1994).

In addition to the basal concentration of $\mathrm{LH}$, greater numbers of testicular receptors for $\mathrm{LH}$ might be important for the increased synthesis of testosterone in bulls treated with GnRH agonist, as shown by Melson et al. (1986). Evidence that LH induces increased numbers and activity of its own receptors has been shown by Kero et al. (2000). This study used transgenic female mice expressing a chimaeric protein derived from the $\alpha$ subunit of bovine LH and the carboxy-terminus peptide extension of the hCG $\beta$ subunit. The animals exhibited chronically increased serum LH concentrations, associated with increased numbers of adrenal LH receptors and steroidogenic capacity.

In animals with increased basal LH concentration, the testicular response observed corresponds to the so-called long-term trophic effect of the hormone on cellular structure and function, which requires mRNA and protein synthesis (Saez, 1994). This long-term response explains the changes in the Leydig cell previously reported, which might be important to maintain increased testosterone synthesis for extended periods in bulls chronically treated with GnRH or GnRH agonists.

The effect of GnRH agonists on FSH concentration in bulls has not been well characterized. Aspden et al. (1996) reported decreased serum FSH concentrations, associated with decreased amounts of $\mathrm{FSH}-\beta$ subunit mRNA in the pituitary, in castrated bulls treated with deslorelin. In contrast, Melson et al. (1986) reported no effect of nafarelin acetate on serum FSH concentrations, but noted a decreased pituitary content of FSH in mature intact bulls. In the present study, there was a slight increase in FSH concentrations in bulls treated with the $\mathrm{GnRH}$ agonist. Whether this increase was biologically important to the extent that it altered testicular function (directly or indirectly on Leydig cells or any other testicular component) is unknown. There is evidence in immature hypophysectomized rats that treatment with highly purified FSH can induce Leydig cell hypertrophy and hyperplasia, associated with increased numbers of $\mathrm{LH}$ receptors and steroidogenic capacity (Teerds et al., 1989; Vihko et al., 1991).

In summary, the present study has shown that chronic infusion with the GnRH agonist, azagly-nafarelin, increases basal $\mathrm{LH}$ and induces a modest increase in FSH mean concentration, associated with increased concentration of testosterone in bulls. In addition, the number and amplitude of LH pulses were reduced by the treatment. In conclusion, these data support the working hypothesis that the functional changes in the testes of bulls chronically treated with $\mathrm{GnRH}$ agonists, associated with enhanced steroidogenesis and testosterone secretion, most likely result from enhanced basal secretion of $\mathrm{LH}$. A possible effect of the small increase of FSH concentration on testicular function cannot be disregarded. The mechanisms inducing increased tonic LH secretion by the downregulated pituitary remain to be elucidated.

The authors acknowledge J. J. Reeves for providing the oLH antibody; L. E. Reichter for providing the oLH and oFSH for iodination; J. A. Dias for providing the oFSH antibody; E. Grotjan, Jr for use of the Four Fit program for analysing radioimmunoassay data; M. Miller, K. Pearson and D. Clopton for technical assistance with the radioimmunoassays; K. Moline, J. Bergman and B. Browelit for their assistance with caring for the bulls; B. Lindsey and E. Zanella for assistance in sample collection and J. Osborne for assistance in editing and revising the manuscript. The academic program of $\mathrm{H}$. Jiménez-Severiano was supported by the National Council for Science and Technology (CONACYT-Mexico) and the National Institute for Research in Forestry, Agriculture and Livestock (INIFAP-Mexico).

This research is published as paper 13673, Journal Series Nebraska Agricultural Research Division, and as paper 33-02AS, Ohio Agricultural Research and Development Center. Research 
was supported by appropriated funds of the State of Nebraska. Mention of a trade name, proprietary product, or specific equipment does not constitute a guarantee or warranty by the USDA and does not imply its approval to the exclusion of other products that may be suitable. The INAD number for use of the $\mathrm{GnRH}$ agonist in this study is 10021 .

\section{References}

Aspden WJ, Rao A, Scott PT, Clarke IJ, Trigg TE, Walsh J and D'Occhio MJ (1996) Direct actions of the luteinizing hormone-releasing hormone agonist, deslorelin, on anterior pituitary contents of luteinizing hormone (LH) and follicle-stimulating hormone (FSH), LH and FSH subunit messenger ribonucleic acid, and plasma concentrations of LH and FSH in castrated male cattle Biology of Reproduction $\mathbf{5 5}$ 386-392

Aspden WJ, Rao A, Rose K, Scott PT, Clarke IJ, Trigg TE, Walsh J and D'Occhio MJ (1997) Differential responses in anterior pituitary luteinizing hormone (LH) content and LH $\beta$ - and $\alpha$-subunit mRNA, and plasma concentrations of $\mathrm{LH}$ and testosterone, in bulls treated with the LH-releasing hormone agonist deslorelin Domestic Animal Endocrinology 14 429-437

Aspden WJ, Rodgers RJ, Stocco DM, Scott PT, Wreford NG, Trigg TE, Walsh J and D'Occhio MJ (1998) Changes in testicular steroidogenic acute regulatory (StAR) protein, steroidogenic enzymes and testicular morphology associated with increased testosterone secretion in bulls receiving the luteinizing hormone-releasing hormone agonist deslorelin Domestic Animal Endocrinology 15 227-238

Bergfeld EGM, D'Occhio MJ and Kinder JE (1996a) Pituitary function, ovarian follicular growth, and plasma concentrations of $17 \beta$-estradiol and progesterone in prepubertal heifers during and after treatment with the luteinizing hormone-releasing hormone agonist deslorelin Biology of Reproduction $\mathbf{5 4}$ 776-782

Bergfeld EGM, D'Occhio MJ and Kinder JE (1996b) Continued desensitization of the pituitary gland in young bulls after treatment with the luteinizing hormone-releasing hormone agonist deslorelin Biology of Reproduction $\mathbf{5 4}$ 769-775

Bint Akhtar F, Marshall GR, Wickings EJ and Nieschlag E (1983) Reversible induction of azoospermia in rhesus monkeys by constant infusion of a gonadotropin-releasing hormone agonist using osmotic minipumps Journal of Clinical Endocrinology and Metabolism $\mathbf{5 6}$ $534-540$

Caraty A, Locatelli A, Delaleu B, Spitz IM, Schatz B and Bouchard P (1990) Gonadotropin-releasing hormone $(\mathrm{GnRH})$ agonists and antagonists do not alter endogenous $\mathrm{GnRH}$ secretion in short-term castrated rams Endocrinology 127 2523-2529

Chase DJ, Schanbacher BD and Lunstra DD (1988) Effects of pulsatile and continuous luteinizing hormone $(\mathrm{LH})$ infusions on testosterone responses to $\mathrm{LH}$ in rams actively immunized against gonadotropinreleasing hormone Endocrinology 123 816-826

D'Occhio MJ and Aspden WJ (1996) Characteristics of luteinizing hormone (LH) and testosterone secretion, pituitary responses to LH-releasing hormone (LHRH), and reproductive function in young bulls receiving the LHRH agonist deslorelin: effect of castration on $\mathrm{LH}$ responses to LHRH Biology of Reproduction $\mathbf{5 4} 45-52$

Davis T, Mussard M, Jiménez-Severiano $\mathrm{H}$, Enright WJ and Kinder JE (2000) Enhanced luteal function in cattle chronically administered with gonadotropin releasing hormone $(\mathrm{GnRH})$ azagly-nafarelin Biology of Reproduction 62 Supplement 1211 (Abstract)

Fraser HM and Lincoln GA (1980) Effects of chronic treatment with an LHRH agonist on the secretion of $\mathrm{LH}, \mathrm{FSH}$ and testosterone in the ram Biology of Reproduction 22 269-276

Gong JG, Bramley TA, Gutierrez CG, Peters AR and Webb R (1995) Effects of chronic treatment with a gonadotrophin-releasing hormone agonist on peripheral concentrations of $\mathrm{FSH}$ and $\mathrm{LH}$, and ovarian function in heifers Journal of Reproduction and Fertility 105 263-270

Grotjan HE, Jr and Steinberg E (1978) A micro-scale method for liquid scintillation counting, applicable to radioimmunoassay for steroids and substances of comparable relative molecular mass Clinical Chemistry 24 1193-1195

Kero J, Poutanen M, Zhang FP, Rahman N, MacNicol AM, Nilson JH, Keri RA and Huhtaniemi IT (2000) Elevated luteinizing hormone induces expression of its receptor and promotes steroidogenesis in the adrenal cortex Journal of Clinical Investigation 105 633-641

Labrie F, Cusan L, Séguin C, Bélanger A, Pelletier G, Reeves JJ, Kelly PA, Lemay A and Raynud JP (1980) Antifertility effects of LHRH agonists in the male rat and inhibition of testicular steroidogenesis in man International Journal of Fertility 25 157-170

Lincoln GA, Fraser HM and Abbott MP (1986) Blockade of pulsatile LH, $\mathrm{FSH}$ and testosterone secretion in rams by constant infusion of an LHRH agonist Journal of Reproduction and Fertility 77 587-597

Littell RC, Milliken GA, Stroup WW and Wolfinger RD (1996) SAS System for Mixed Models pp 87-134. SAS Institute Inc., Cary, NC

Melson BE, Brown JL, Schoenemann HM, Tarnavsky GK and Reeves JJ (1986) Elevation of serum testosterone during chronic LHRH agonist treatment in the bull Journal of Animal Science 62 199-207

Mendis-Handagama SMLC, Watkins PA, Gelber SJ and Scallen TJ (1998) The effect of chronic luteinizing hormone treatment on adult rat Leydig cells Tissue and Cell 30 64-73

Merriam GR and Wachter KW (1982) Algorithms for the study of episodic hormone secretion American Journal of Physiology 243 E310-E318

O'Shaughnessy PJ and Payne HA (1982) Differential effects of single and repeated administration of gonadotropins on testosterone production and steroidogenic enzymes in Leydig cell populations Journal of Biological Chemistry 25711 503-11509

Payne HA, Wong KL and Vega MM (1980) Differential effect of single and repeated administration of gonadotropins on luteinizing hormone receptor and testosterone synthesis in two populations of Leydig cells Journal of Biological Chemistry 255 7118-7122

Ronayne E, Enright WJ and Roche JF (1993) Effects of continuous administration of gonadotropin-releasing hormone $(\mathrm{GnRH})$ or a potent $\mathrm{GnRH}$ analogue on blood luteinizing hormone and testosterone concentrations in prepubertal bulls Domestic Animal Endocrinology 10 179-189

Saez JM (1994) Leydig cells: endocrine, paracrine, and autocrine regulation Endocrine Reviews 15 574-626

Schürmeyer T, Knuth UA, Freuschem CW, Sandow J, Bint Akhtar F and Nieschlag E (1984) Suppression of pituitary and testicular function in normal men by constant gonadotropin-releasing hormone agonist infusion Journal of Clinical Endocrinology and Metabolism 58 19-24

Sundaram K, Thau RB, Goldstein M, Phillips DM, Rivier JE, Vale W and Bardin CW (1984) Effect of an LHRH agonist on pituitary and testicular function in rhesus monkeys Journal of Reproduction and Fertility 72 365-371

Teerds KJ, Closset J, Rommerts FFG, De Rooij DG, Stocco DM, Colenbrander B, Wensing GJG and Hennen G (1989) The effects of pure $\mathrm{FSH}$ or $\mathrm{LH}$ preparations on the number and functions of Leydig cells in immature hypophysectomized rats Journal of Endocrinology 120 97-106

Vickery BH, MacRae GI, Briones WV, Roberts BB, Worden AC, Schanbacher BD and Falvo RE (1985) Dose-response studies on male reproductive parameters in dogs with nafarelin acetate, a potent $\mathrm{LHRH}$ agonist Journal of Andrology 653-60

Vihko KK, LaPolt PS, Nishimori K and Hsueh AJW (1991) Stimulatory effects of recombinant follicle-stimulating hormone on Leydig cell function and spermatogenesis in immature hypophysectomized rats Endocrinology 129 1926-1932

Wolfe MW, Stumpf TT, Roberson MS, Wolfe PL, Kittok RJ and Kinder JE (1989) Estradiol influences on pattern of gonadotropin secretion in bovine males during the period of changed responses to estradiol feedback in age-matched females Biology of Reproduction 41 626-634

Received 15 May 2002

First decision 22 July 2002.

Revised manuscript received 20 August 2002.

Accepted 4 October 2002. 